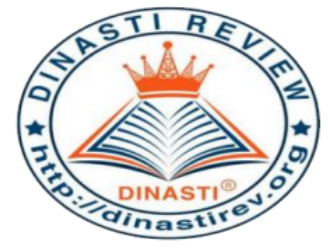

+62 878-9658-6407 087896586407

https://dinastirev.org/JIMT editor@dinastirev.org

\title{
PENGARUH PERSEPSI SISWA TENTANG KOMPETENSI PEDAGOGIK GURU, LINGKUNGAN KELUARGA DAN TEMAN SEBAYA TERHADAP HASIL BELAJAR IPS SISWA KELAS VIII SMP N 10 KOTA JAMBI
}

\section{Reni Anggraeni ${ }^{1}$, Ekawarna ${ }^{2}$, Kamid $^{3}$}

1) Alumni Program Magister Pendidikan Ekonomi Univeritas Jambi, Jambi, Indonesia

2) Univeritas Jambi, Kota Jambi, Indonesia

3) Univeritas Jambi, Kota Jambi, Indonesia

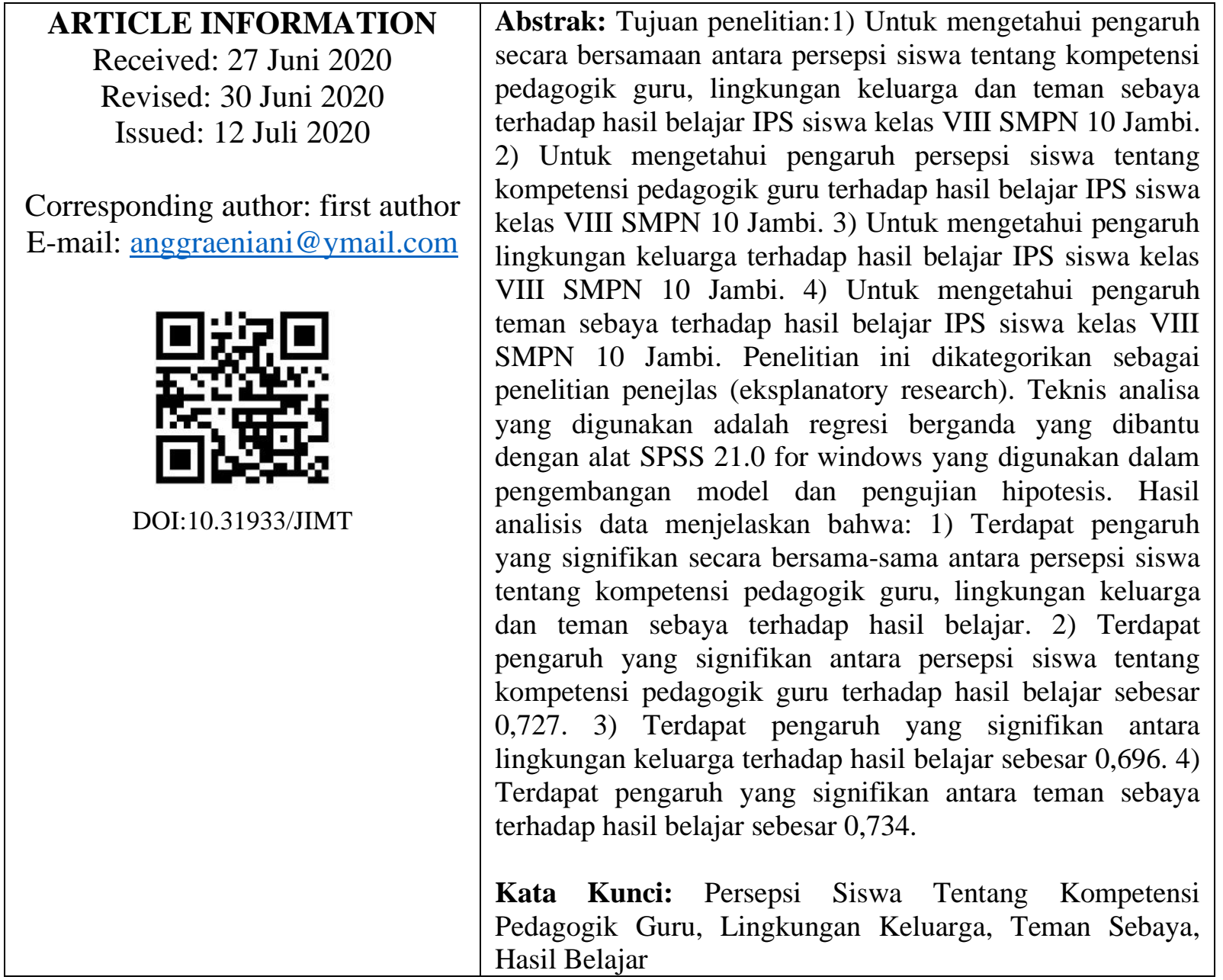

\section{PENDAHULUAN}

Proses pembelajaran merupakan suatu sistem yang bertujuan untuk meningkatkan kualitas pendidikan. Pendidikan dikatakan berhasil apabila tujuan dari pembelajaran dapat disampaikan kepada siswa sehingga memberikan perubahan yang lebih baik bagi siswa. Keberhasilan dalam pembelajaran dapat dilihat outputnya yaitu hasil belajar. Hasil belajar merupakan penguasaan pengetahuan, keterampilan, dan sikap yang didapatkan oleh siswa 
selama mengikuti proses pembelajaran yang ditunjukkan dengan angka melalui pengujian atau tes dan ditandai dengan skala nilai berupa huruf atau simbol. Hasil belajar dapat dilihat dari nilai ulangan, nilai ujian tengah semester, dan nilai akhir semester. Hasil akhir dari setiap siswa tentu berbeda-beda. Ada yang mendapatkan nilai tinggi tetapi ada juga yang mendapatkan nilai yang rendah atau dibawah Kriteria Ketuntasan Minimum (KKM).

Sekolah Menengah Pertama (SMP) Negeri 10 Jambi merupakan salah satu SMP Negeri dengan jumlah siswa yang terbilang cukup banyak. Selain itu SMPN 10 Jambi juga mempunyai visi dan misi yang mulia. Dimana salah satu mata pelajaran disekolah ini adalah IPS. Berdasarkan hasil observasi awal yang dilakukan, diketahui bahwa nilai IPS siswa masih tergolong rendah hingga semester ganjil ditahun 2019/2020. Menurut Muhibbin Syah (2013) faktor yang mempengaruhi hasil belajar siswa yaitu faktor yang berasal dari dalam diri siswa dan faktor yang berasal dari luar diri siswa. Faktor yang berasal dari luar diri siswa, yaitu : 1) faktor lingkungan sosial yang meliputi guru, keluarga, teman sebaya, masyarakat dan tetangga. 2) faktor lingkungan nonsosial yang meliputi gedung sekolah dan letaknya, rumah tempat tinggal dan alat-alat belajar.

Dalam penelitian ini, kompetensi guru yang akan diteliti adalah kompetensi pedagogik yang diukur melalui persepsi siswa. Seorang guru profesional dituntut untuk bisa memberikan pembelajaran dengan memanfaatkan media teknologi, seperti penggunaan komputer, powerpoint, dan media lainnya yang akan mempermudah guru dalam pembelajaran dikelas. Apabila persepsi siswa tentang kompetensi pedagogik guru positif maka kehadiran guru dalam mengajar akan direspon positif pula oleh siswa, hasil belajar sebagai dampak dari persepsi tersebut juga akan baik, misalnya menggunakan strategi belajar yang aktif dan menyenangkan, sehingga seluruh siswa akan merasa senang dan tidak berniat menimbulkan keributan yang tidak berarti ketika proses pembelajaran.

Selain pihak sekolah, peran keluarga juga diperlukan didalamnya. Keluarga merupakan lingkungan yang paling mendasar terhadap perubahan dan perkembangan individu karena pada hakikatnya lingkungan keluarga merupakan tempat utama bagi seseorang dalam melaksanakan proses belajarnya. Orang tua memiliki tanggung jawab dalam kesuksesan anak disekolah. Nilai yang diperoleh anak disekolah tidak terlepas dari peran orang tua yang mengawasi belajar anak dirumah, karena waktu yang digunakan guru untuk mengajar siswa disekolah sangat terbatas. Sehingga perlunya peran orang tua dalam proses belajar dirumah.

Faktor lain yang juga mempengaruhi hasil belajar siswa adalah teman sebaya. Menurut Santrock (2009) teman sebaya merupakan anak atau remaja yang mempunyai tingkat umur dan tingkat kedewasaan yang sama. Jika hubungan dengan teman sebaya yang positif maka akan berdampak baik dan jika hubungannya negatif maka akan berdampak buruk bagi siswa.

Tujuan dalam penelitian ini untuk mengetahui pengaruh secara bersama-sama antara persepsi siswa tentang kompetensi pedagogik guru, lingkungan keluarga dan teman sebaya terhadap hasil belajar IPS siswa kelas VIII SMPN 10 Jambi, untuk mengetahui pengaruh persepsi siswa tentang kompetensi pedagogik guru terhadap hasil belajar IPS siswa kelas VIII SMPN 10 Jambi, untuk mengetahui pengaruh lingkungan keluarga terhadap hasil belajar IPS siswa kelas VIII SMPN 10 Jambi dan untuk mengetahui pengaruh teman sebaya terhadap hasil belajar IPS siswa kelas VIII SMPN 10 Jambi. Definisi konseptual dalam penelitian ini adalah hasil belajar IPS. Hasil belajar IPS merupakan perubahan perilaku setelah siswa kelas VIII SMPN 10 Jambi mengikuti proses belajar mata pelajaran IPS. Penelitian ini tidak melakukan pengukuran terhadap variabel hasil belajar, sehingga skor yang digunakan 
diperoleh dari guru melalui nilai ujian semester. Selanjutnya persepsi siswa tentang kompetensi pendagogik guru. Persepsi siswa tentang kompetensi pendagogik guru adalah kesan/pesan yang diberikan siswa kelas VIII di SMP N 10 Jambi terhadap guru IPS mereka diskeolah. Lingkungan keluarga, lingkungan keluarga siswa kelas VIII di SMP N 10 Jambi adalah bagaimana cara orang tua mereka mendidik, memperhatikan dan memfasilitasi proses pembelajaran IPS siswa baik dirumah maupun disekolah. Teman sebaya, dimana teman sebaya adalah sekelompok orang atau siswa yang sama-sama bersekolah di SMP N 10 Jambi yang saling mempengaruhi dalam berbagai hal, serta memiliki kesamaan sosial.

\section{KAJIAN PUSTAKA}

\section{Hasil Belajar IPS}

Hasil belajar IPS merupakan hasil maksimal siswa dalam aspek kognitif, afektif, ataupun psikomotorik yang diperoleh setelah memperlajari maeri IPS dengan jalan mencari berbagai informasi yang dibutuhkan baik berupa perubahan tingkah laku, pengetahuan, maupun keterampilan sehingga siswa mampu meraih hasil belajar yang maksimal sekaligus memecahkan masalah yang berkaitan dengan masalah sosial dan menerapkannya dalam kehidupan.

Menurut Slameto (2010) faktor-faktor yang mempengaruhi belajar banyak jenisnya, tetapi dapat digolongkan menjadi dua golongan saja, yaitu faktor intern dan faktor ekstern. Faktor intern adalah faktor yang berasaldari dalam diri individu yang sedang belajar. Ada tiga faktor yang menjadi faktor intern yaitu Kesehatan, Intelegensi dan Bakat, Minat dan Motivasi serta Cara Belajar. Sedangkan untuk faktor ekstern yaitu faktor Keluarga, Sekolah dan Masyarakat.

\section{Pesepsi Siswa Tentang Kompeteni Pedagogik Guru}

Menurut Sugihartono (2007) persepsi adalah kemampuan otak dalam menerjemahkan stimulus atau proses untuk menerjemahkan/ mengintrepetasi stimulus yang masuk kedalam alat indera. Persepsi siswa tentang kompetensi pedagogik guru dapat diartikan sebagai kesan/penilaian yang diberikan oleh siswa tentang kompetensi pedagogik guru dan akan muncul setelah mengamati sesuatu, persepsi tersebut berkenaan dengan pemahaman karakteristik siswa serta kemampuan guru menciptakan suasana pembelajaran yang menyenangkan.

Siswa yang mempunyai persepsi yang positif tentang kompetensi pedagogik guru maka akan berpengaruh pada motivasi belajarnya, siswa akan lebih bersemangat mengikuti pelajaran. Sebaliknya apabila siswa mempunyai persepsi yang negatif maka siswa kurang bersemangat mengikuti pelajaran.

Indikator Persepsi Tentang Kompetensi Pedagogik Guru: a) Menyelenggarakan pembelajaran yang mendidik; b) Memanfaatkan teknologi informasi dan komunikasi untuk kepentingan pembelajaran; c) Memfasilitasi pengembangan potensi peserta didik untuk mengaktualisasikan berbagai potensi yang dimiliki; d) Berkomunikasi secara efektif, empatik dan santun terhadap peserta didik; e) Menyelenggarakan penilaian dan evaluasi hasil belajar; dan f) Memanfaatkan hasil penilaian dan evaluasi untuk kepentingan pembelajaran.

\section{Lingkungan Keluarga}


Menurut Sertain (Dalyono 2001) "Lingkungan meliputi semua kondisi-kondisi dalam dunia ini yang dalam cara-cara tertentu mempengaruhi tingkah laku kita, pertumbuhan, perkembangan kita kecuali gen-gen, dan gen-gen dapat pula dipandang menyiapkan lingkungan bagi gen yang lain”. Dapat disimpulkan bahwa lingkungan merupakan segala sesuatu yang ada di dalam ataupun di luar individu baik yang bersifat fisiologis, psikologis, maupun sosio-kultural yang berpengaruh tertentu terhadap individu.

Indikator Lingkungan Keluarga: a) Cara Orang Tua Mendidik; b) Suasana Rumah atau Keluarga; dan c) Keadaan Ekonomi Keluarga.

\section{Teman Sebaya}

Menurut Santrock (2007) sebaya adalah orang dengan tingkat umur dan kedewasaan yang kira-kira sama. Jali (2006) berpendapat bahwa sebaya adalah mereka yang lahir pada waktu yang sama dan memiliki usia yang sama. Teman sebaya menurut Zainal Madon dan Mohd. Sharani Ahmad (2004) adalah kelompok anak-anak atau remaja yang sama umur atau peringkat perkembangannya.

Teman Sebaya adalah suatu lingkungan yang terdiri dari sekelompok orang yang mempunyai kesamaan sosial seperti kesamaan tingkat dengan berbagai karakter individu yang mampu mempengaruhi perilaku individu. Teman sebaya termasuk didalamnya Lingkungan Teman Sebaya di lingkungan tempat tinggal maupun di lingkungan tempat belajar. Diantara teman sebaya saling mengadakan interaksi, sehingga terjadi keterlibatan individu di dalamnya yang akhirnya akan terjadi dorongan dan dukungan yang dapat mempengaruhi dan memotivasi seseorang untuk berminat terhadap sesuatu.

Indikator Teman Sebaya: a) Kerjasama; b) Persaingan; c) Pertentangan; d) Persesuaian/Akomodasi; dan e) Perpaduan/Asimilasi.

\section{Kerangka Berpikir}

Adapun paradigma dari kerangka pemikiran dari penelitian dapat digambarkan sebagai berikut:

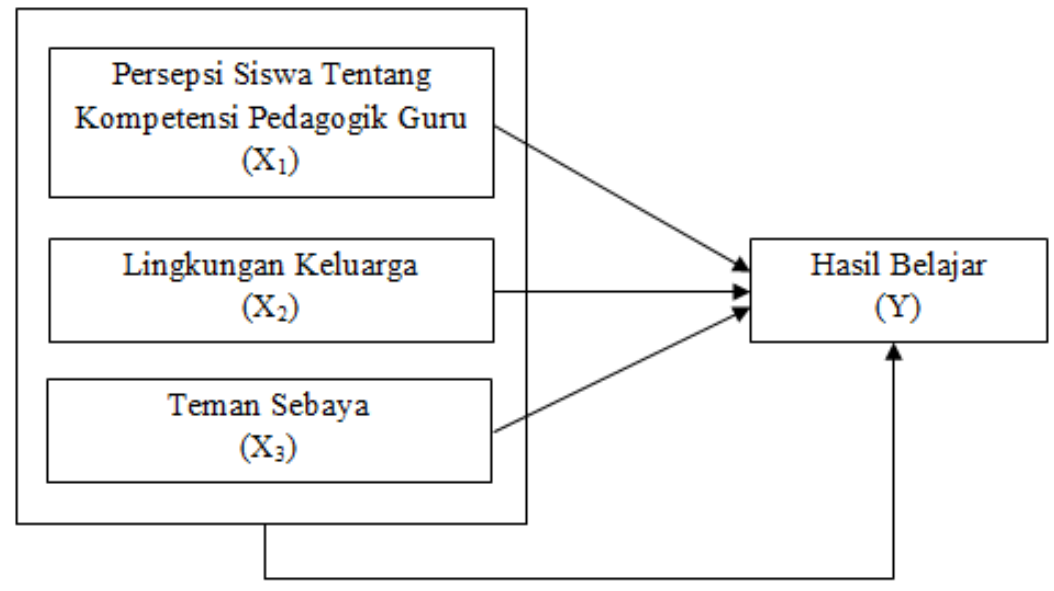

Gambar 1. Kerangka Berpikir

\section{Hipotesis}


1. Persepsi tentang kompetensi pedagogik guru, lingkungan keluarga dan teman sebaya secara bersama-sama berpengaruh signifikan terahadap hasil belajar IPS siswa kelas VIII di SMPN 10 Kota Jambi.

2. Persepsi tentang kompetensi pedagogik guru berpengaruh signifikan terahadap hasil belajar IPS siswa kelas VIII di SMP N 10 Kota Jambi.

3. Lingkungan keluarga berpengaruh signifikan terahadap hasil belajar IPS siswa kelas VIII di SMP N 10 Kota Jambi.

4. Teman sebaya berpengaruh signifikan terahadap hasil belajar IPS siswa kelas VIII di SMP N 10 Kota Jambi.

\section{METODE PENELITIAN}

\section{Rancangan Penelitian}

Penelitian ini dilakukan untuk melihat pengaruh persepsi siswa tentang kompetensi pedagogik guru, lingkungan keluarga dan teman sebaya terhadap hasil belajar. Penelitian menggunakan cakupan waktu bersifat cross section/one shoot, yang berarti informasi atau data yang diperoleh adalah hasil pengumpulan data yang dilakukan pada satu waktu tertentu (Sugiyono, 2017).

Penelitian ini menggunakan metode penelitian kombinasi (Mixed Methods). Menurut Sugiyono (2017), metode penelitian kombinasi (mixed methods) adalah suatu metode penelitian yang mengkombinasikan atau menggabungkan antara metode kuantitatif dan metode kualitatif untuk digunakan secara bersama-sama dalam suatu kegiatan penelitian sehingga diperoleh data yang lebih komprehensif, valid, reliabel dan objektif sehingga diperoleh data yang lebih lengkap dan menyeluruh.

\section{Tempat dan Waktu Penelitian}

Tempat penelitian adalah SMPN 10 Jambi yang beralamat di Komplek Tri Tura, Jalan Pangeran Diponegoro, Rajawali Kecamatan Jambi Timur. Waktu penelitian dilaksanakan pada bulan Maret.

\section{Subjek Penelitian}

Suharsimi (2013) menyatakan bahwa Populasi adalah keseluruhan subjek penelitian. Peneliti memilih untuk menjadikan seluruh populasi tersebut sebagai sampel dalam penelitian ini. maka dari itu, subjek penelitian ini adalah seluruh siswa kelas VIII SMP Negeri 10 Kota Jambi yang berjumlah 149 orang. Keseluruhan subjek tersebut akan dikenai generalisasi dari hasil penelitian.

\section{Instrumen Penelitian}

Instrumen penelitian digunakan untuk mengukur nilai variabel yang di teliti. Jumlah instrumen penelitian tergantung pada jumlah variabel yang ditetapkan untuk diteliti. Skala Likert digunakan untuk mengukur Skala Likert ini digunakan untuk mengukur sikap, pendapat, minat dan persepsi seseorang atau sekelompok orang tentang fenomena sosial (Sugiyono, 2017)

\section{Teknik Pengumpulan Data}

1. Kuesioner 
2. Dokumentasi

3. Wawancara

\section{Analisis Deskriptif}

Langkah awal untuk menganalisa data pada penelitian ini yaitu:

1. Menghitung skor-skor dari setiap butir soal kemudian skor-skor tersebut dijumlahkan untuk mendapatkan skor total.

2. Menentukan range $=$ skor tertinggi - skor terendah.

3. Untuk menentukan banyaknya kelas dengan melihat banyak kategori yang digunakan dalam penelitian ini ada 5 kategori, yaitu sangat baik, baik, cukup baik, buruk, dan sangat buruk.

4. Menentukan panjang interval dengan rumus:

$$
\text { Panjang Interval }=\frac{\text { Range }}{\text { Jumlah Kelas }}
$$

5. Kemudian di konversikan kedalam tabel kriteria penafsiran skor.

\section{Uji Prasyarat}

Uji prasyarat yang digunakan adalah Uji Normalitas, Uji Multikoloniearitas, Uji Heterokedastisitas dan Uji Linieritas.

\section{Analisis Regresi Berganda}

Analisis berganda adalah persamaan dengan kemungkinan yang mendekati kenyataan antara variabel yang ada dan untuk mengukur pengaruh antar variabel bebas dengan variabel terikat, dengan menggunakan SPSS.

Analisis berganda adalah persamaan dengan kemungkinan yang mendekati kenyataan antara variabel yang ada dan untuk mengukur pengaruh antar variabel bebas dengan variabel terikat, dengan menggunakan SPSS.

\section{Uji Hipotesis}

Uji Hipotesis yang digunakan adalah Koefisien Determinasi, Uji F dan Uji t.

\section{Teknik Keabsahan Data}

Alat pengumpulan data pada bagian kualitatif dalam penelitian ini menggunakan metode wawancara. Dalam penelitian ini data hasil wawancara akan dibandingkan dengan data hasil penyebaran kuesioner menggunakan metode triangulasi. Dalam menganalisis data kualitatif dalam penelitian ini adalah dengan melakukan: 1) Reduksi Data; 2) Penyajian Data; dan 3) Penarikan Kesimpulan

\section{Hipotesis Statistik}

1. Ho: $\operatorname{pyx} 1 \times 2 \times 3=0$

$\mathrm{H}_{\mathrm{a}}: \operatorname{pyx} 1 \times 2 \times 3 \neq 0$

2. Но: $\operatorname{pyx} 1=0$

$\mathrm{H}_{\mathrm{a}}: \operatorname{pyx} 1 \neq 0$

3. Ho: $\operatorname{pyx} 2=0$

$\mathrm{H}_{\mathrm{a}}: \operatorname{pyx} 2 \neq 0$

4. Ho: $\operatorname{pyx} 3=0$ 
$\mathrm{H}_{\mathrm{a}}: \operatorname{pyx} 3 \neq 0$

\section{HASIL DAN PEMBAHASAN}

\section{Hasil Penelitian}

Pada bagian ini penulis akan mendeskripsikan variabel yang diteliti satu persatu sebagai berikut:

a. Deskripsi Variabel Persepsi Siswa Tentang Kompetensi Pedagogik Guru ( $\left.\mathrm{X}_{1}\right)$

Berdasarkan data hasil penelitian, diperoleh skor terendah 25 dan skor tertinggi 55. Hasil perhitungan distribusi skor tersebut menghasilkan skor rata-rata sebesar 42,14 dan simpangan baku sebesar 5,43.

\section{b. Deskripsi Variabel Lingkungan Keluarga $\left(\mathbf{X}_{2}\right)$}

Berdasarkan hasil olah data penelitian, diperoleh skor terendah 16 dan skor tertinggi 35. Hasil perhitungan distribusi skor tersebut menghasilkan skor rata-rata sebesar 25,72 dan simpangan baku sebesar 3,757.

\section{c. Deskripsi Variabel Teman Sebaya $\left(\mathbf{X}_{3}\right)$}

Berdasarkan data hasil penelitian, diperoleh skor terendah 30 dan skor tertinggi 65 . Hasil perhitungan distribusi skor tersebut menghasilkan skor rata-rata sebesar 49,27 dan simpangan baku sebesar 6,622.

\section{d. Deskripsi Variabel Hasil Belajar (Y)}

Berdasarkan data hasil penelitian, dterlihat nilai terendah adalah 54 dan nilai tertinggi berada pada angka 88,5. Hasil perhitungan distribusi skor tersebut menghasilkan nilai rata-rata sebesar 75,73 dan simpangan baku sebesar 5,507

\section{Hasil Uji Prasyarat}

1. Uji Normalitas

Tabel 1. Hasil Uji Normalitas

One-Sample Kolmogorov-Smirnov Test

\begin{tabular}{|ll|r|r|r|r|}
\hline & & KPG_X1 & LingKel_X2 & TemSeb_X3 & Hasil_Belajar_Y \\
\hline $\mathrm{N}$ & & 149 & 149 & 149 & 149 \\
Normal Parameters & Mean & 42,141 & 25,718 & 49,275 & 75,7274049 \\
& Std. Deviation & 5,4302 & 3,7580 & 6,6219 & 5,506831368 \\
Most Extreme & Absolute &, 095 &, 113 &, 107 &, 102 \\
Differences & Positive &, 094 &, 113 &, 107 &, 081 \\
Kolmogorov-Smirnov Z & Negative &,- 095 &,- 080 &,- 098 &,- 102 \\
Asymp. Sig. (2-tailed) & 1,164 & 1,375 & 1,308 & 1,247 \\
\hline
\end{tabular}

a. Test distribution is Normal.

b. Calculated from data.

Maka dapat disimpulkan keempat variabel tersebut berdistribusi normal.

\section{Uji Multikolinearitas}

Tabel 2. Hasil Uji Multikolinearitas

\begin{tabular}{|l|r|r|}
\hline \multirow{2}{*}{ Model } & \multicolumn{2}{|c|}{ Collinearity Statistics } \\
\cline { 2 - 3 } & \multicolumn{1}{|c|}{ Tolerance } & \multicolumn{1}{|c|}{ VIF } \\
\hline \multirow{2}{*}{ (Constant) } & & \\
1 & & \\
KPG_X1 &, 208 & 4,815 \\
LingKel_X2 &, 275 & 3,637 \\
TemSeb_X3 &, 169 & 5,929 \\
\hline
\end{tabular}


Dapat disimpulkan bahwa tidak terjadi multikoloniearitas antar variabel independent dalam model regresi.

\section{Uji Heterokedastisitas}

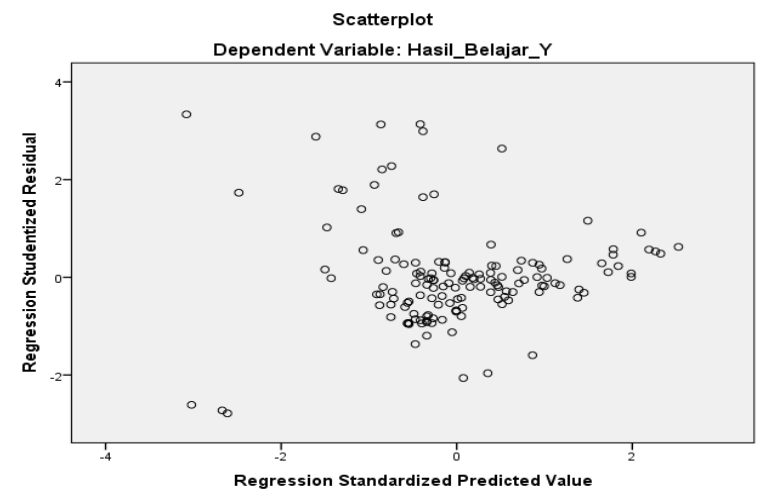

Gambar 2. Scatterplot Heterokedastisitas

Dari gambar scatterplots diatas dapat dilihat bahwa titik-titik menyebar secara acak serta tersebar baik diatas maupun dibawah angka 0 pada sumbu Y. Hal ini dapat disimpulkan bahwa tidak terjadi heterokedastisitas pada model, sehingga model layak dipakai untuk memprediksi penggunaan jasa akomodasi berdasarkan masukan variabel independent.

\section{Uji Linieritas}

\section{Hasil Uji Linieritas Persepsi Siswa Tentang Kompetensi Pedagogik $\left(\mathbf{X}_{1}\right)$}

Tabel 3. Hasil Uji Linieritas $\left(\mathrm{X}_{1}\right)$ ANOVA Table

\begin{tabular}{|c|c|c|c|c|c|c|c|}
\hline & & & $\begin{array}{l}\text { Sum of } \\
\text { Squares }\end{array}$ & $d f$ & $\begin{array}{l}\text { Mean } \\
\text { Square }\end{array}$ & $\mathrm{F}$ & Sig. \\
\hline \multirow{5}{*}{$\begin{array}{l}\text { Hasil_Belajar_Y * } \\
\text { KPG_X1 }\end{array}$} & & (Combined) & 2922,058 & 24 & 121,752 & 2,640 & ,079 \\
\hline & Between & Linearity & 2373,523 & 1 & 2373,523 & 7,933 & ,013 \\
\hline & Groups & $\begin{array}{l}\text { Deviation } \\
\text { from Linearity }\end{array}$ & 548,535 & 23 & 23,849 & ,788 & ,114 \\
\hline & \multicolumn{2}{|c|}{ Within Groups } & 1566,070 & 124 & 12,630 & & \\
\hline & \multicolumn{2}{|l|}{ Total } & 4488,128 & 148 & & & \\
\hline
\end{tabular}

Berdasarkan tabel diatas dapat dilihat bahwa variabel persepsi siswa tentang kompetensi pedagogik guru $\left(\mathrm{X}_{1}\right)$ dalam penelitian ini diperoleh nilai dari sig deviation from linearity sebesar 0,114>0,05, maka model regresi bersifat linier.

\section{Hasil Uji Linieritas Variabel Lingkungan Keluarga $\left(\mathbf{X}_{2}\right)$}

Tabel 4. Hasil Uji Linieritas $\left(\mathrm{X}_{2}\right)$

\begin{tabular}{|c|c|c|c|c|c|c|c|}
\hline \multicolumn{8}{|c|}{ ANOVA Table } \\
\hline & & & $\begin{array}{l}\text { Sum of } \\
\text { Squares }\end{array}$ & $\mathrm{df}$ & $\begin{array}{l}\text { Mean } \\
\text { Square }\end{array}$ & $F$ & Sig. \\
\hline \multirow{5}{*}{$\begin{array}{l}\text { Hasil_Belajar_Y * } \\
\text { LingKel_X2 }\end{array}$} & & (Combined) & 2818,411 & 19 & 148,337 & 1,460 & ,076 \\
\hline & Between & Linearity & 2171,178 & 1 & 2171,178 & 6,742 & ,011 \\
\hline & Groups & Deviation & 647,233 & 18 & 35,957 & ,278 & ,097 \\
\hline & Within $G r$ & Ins & 1669.718 & 129 & 12,944 & & \\
\hline & Total & & 4488,128 & 148 & & & \\
\hline
\end{tabular}


Berdasarkan tabel diatas dapat dilihat bahwa variabel lingkungan keluarga $\left(\mathrm{X}_{2}\right)$ dalam penelitian ini diperoleh nilai dari sig deviation from linearity sebesar 0,097>0,05, maka model regresi bersifat linier.

\section{Hasil Uji Linieritas Variabel Teman Sebaya}

Tabel 5. Hasil Uji Linieritas $\left(\mathrm{X}_{3}\right)$

ANOVA Table

\begin{tabular}{|c|c|c|c|c|c|c|c|}
\hline & & & $\begin{array}{l}\text { Sum of } \\
\text { Squares }\end{array}$ & $\mathrm{df}$ & $\begin{array}{l}\text { Mean } \\
\text { Square }\end{array}$ & $\mathrm{F}$ & Sig. \\
\hline \multirow{5}{*}{$\begin{array}{l}\text { Hasil_Belajar_Y * } \\
\text { TemSeb_X3 }\end{array}$} & & (Combined) & 3502,805 & 33 & 106,146 & 2,389 & ,085 \\
\hline & Between & Linearity & 2419,481 & 1 & 2419,481 & 8,385 & ,018 \\
\hline & Groups & Deviation & 1083,324 & 32 & 33,854 & ,751 & ,321 \\
\hline & \multicolumn{2}{|c|}{ Within Groups } & 985,323 & 115 & 8,568 & & \\
\hline & \multicolumn{2}{|l|}{ Total } & 4488,128 & 148 & & & \\
\hline
\end{tabular}

Berdasarkan tabel diatas dapat dilihat bahwa variabel teman sebaya $\left(\mathrm{X}_{3}\right)$ dalam penelitian ini diperoleh nilai dari sig deviation from linearity sebesar 0,321 >0,05, maka model regresi bersifat linier.

\section{Hasil Analisis Regresi Berganda} berikut:

Berikut ini merupakan hasil analisis regresi berganda yang dirangkum dalam tabel

Tabel 6. Coefficients Regresi Berganda

Coefficients $^{\mathrm{a}}$

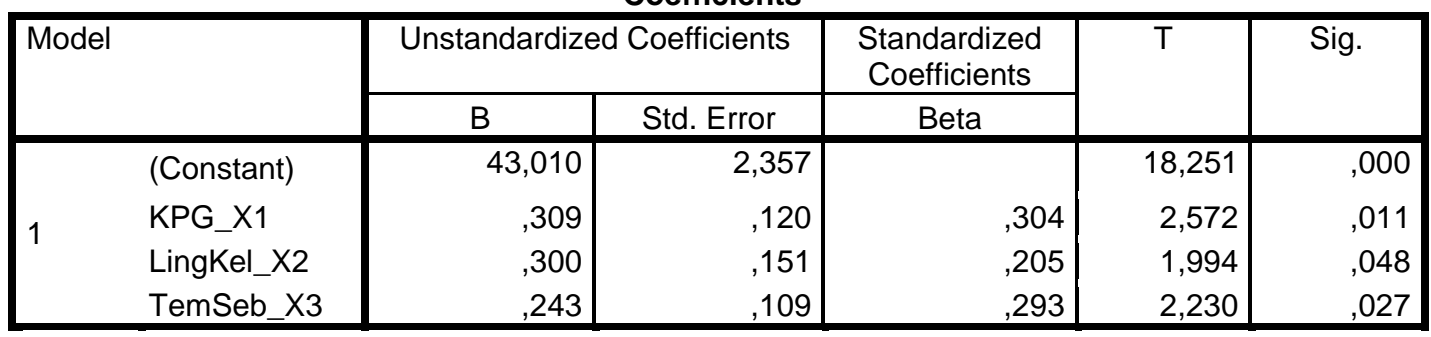

a. Dependent Variable: Hasil_Belajar_Y

\section{Pengujian Hipotesis Pertama}

Hipoteis pertama dalam penelitian ini adalah persepsi siswa tentang kompetensi pedagogik guru, lingkungan keluarga dan teman sebaya secara bersama-sama berpengaruh signifikan terhadap hasil belajar. Hal ini dapat dilihat melalui tabel diatas. Sesuai perhitungan tabel tersebut dapat disimpulkan bahwa hipotesis pertama yang diajukan dapat diteima.

\section{Pengujian Hipotesis Kedua}

Tabel 7. Hasil Perhitngan Hipotesis Kedua Coefficients $^{a}$

\begin{tabular}{|c|c|c|c|c|c|c|}
\hline \multirow{2}{*}{\multicolumn{2}{|c|}{ Model }} & \multicolumn{2}{|c|}{ Unstandardized Coefficients } & Standardized & \multirow[t]{2}{*}{$\mathrm{T}$} & \multirow[t]{2}{*}{ Sig. } \\
\hline & & $B$ & Std. Error & Beta & & \\
\hline \multirow{2}{*}{1} & (Constant) & 44,649 & 2,439 & & 18,304 &, 000 \\
\hline & $\mathrm{KPG} \times 1$ & 737 & 057 & ,727 & 12,845 &, 000 \\
\hline
\end{tabular}

a. Dependent Variable: Hasil_Belajar_Y 
Berdasarkan hasil perhitungan diatas dapat disimpulkan bahwa hipotesis kedua yang diajukan dapat diterima.

\section{Pengujian Hipotesis Ketiga}

Tabel 8. Hasil Perhitungan Hipotesis Ketiga Coefficients $^{\mathrm{a}}$

\begin{tabular}{|c|c|c|c|c|c|c|}
\hline \multirow{2}{*}{\multicolumn{2}{|c|}{ Model }} & \multicolumn{2}{|c|}{ Unstandardized Coefficients } & Standardized & \multirow[t]{2}{*}{$\mathrm{T}$} & \multirow[t]{2}{*}{ Sig. } \\
\hline & & $B$ & Std. Error & Beta & & \\
\hline \multirow{2}{*}{1} & (Constant) & 49,516 & 2,257 & & 21,940 & ,000 \\
\hline & LingKel_X2 & 1,019 & 087 & 696 & 11,737 &, 000 \\
\hline
\end{tabular}

\section{Pengujian Hipotesis Keempat}

Tabel 9. Hasil Perhitungan Hipotesis Keempat

Coefficients $^{a}$

\begin{tabular}{|c|c|c|c|c|c|c|}
\hline \multirow{2}{*}{\multicolumn{2}{|c|}{ Model }} & \multicolumn{2}{|c|}{ Unstandardized Coefficients } & Standardized & \multirow[t]{2}{*}{$\mathrm{T}$} & \multirow[t]{2}{*}{ Sig. } \\
\hline & & $B$ & Std. Error & Beta & & \\
\hline \multirow{2}{*}{1} & (Constant) & 45,641 & 2,315 & & 19,715 &, 000 \\
\hline & TemSeb_X3 & ,611 & ,047 & ,734 & 13,112 & ,000 \\
\hline
\end{tabular}

a. Dependent Variable: Hasil_Belajar_Y

Berdasarkan hasil perhitungan diatas dapat disimpulkan bahwa hipotesis kedua yang diajukan dapat diterima.

\section{Pembahasan}

1. Pengaruh Persepsi Siswa Tentang Kompetensi Pedagogik Guru, Lingkungan Keluarga Dan Teman Sebaya Terhadap Hasil Belajar

Berdasarkan pegujian hipotesis yang dilakukan, persepsi siswa tentang kompetensi pedagogik guru, lingkungan keluarga dan teman sebaya berpengaruh positif dan signifikan terhadap hasil belajar.

2. Pengaruh Persepsi Siswa Tentang Kompetensi Pedagogik Guru Terhadap Hasil Belajar

Berdasarkan pegujian hipotesis yang dilakukan, diketahui bahwa persepsi siswa tentang kompetensi pedagogik guru berpengaruh positif dan signifikan terhadap hasil belajar.

3. Pengaruh Lingkungan Keluarga Terhadap Hasil Belajar

Berdasarkan pegujian hipotesis yang dilakukan, diketahui bahwa lingkungan keluarga berpengaruh positif dan signifikan terhadap hasil belajar.

\section{Pengaruh Teman Sebaya Terhadap Hasil Belajar}

Berdasarkan pegujian hipotesis yang dilakukan, diketahui bahwa teman sebaya berpengaruh positif dan signifikan terhadap hasil belajar. 


\section{KESIMPULAN DAN SARAN}

\section{Kesimpulan}

Berdasarkan hasil penelitian yang diperoleh secara keseluruhan, maka dapat disimpukan sebagai berikut:

1. Berdasarkan hasil analisis perhitungan dan wawancara, dapat disimpulkan bahwa persepsi siswa tentang kompetensi pedagogik guru, lingkungan keluarga dan teman sebaya berpengaruh signifikan terhadap hasil belajar.

2. Berdasarkan hasil analisis perhitungan dan wawancara, dapat disimpulkan bahwa persepsi siswa tentang kompetensi pedagogik guru, berpengaruh signifikan terhadap hasil belajar.

3. Berdasarkan hasil analisis perhitungan dan wawancara, dapat disimpulkan bahwa lingkungan keluarga berpengaruh signifikan terhadap hasil belajar.

4. Berdasarkan hasil analisis perhitungan dan wawancara, dapat disimpulkan bahwa teman sebaya berpengaruh signifikan terhadap hasil belajar.

\section{Saran}

\section{A. Bagi Sekolah}

Pihak sekolah, terutama guru IPS sebaiknya memahami bahwa hasil belajar IPS siswa cukup rendah dipengaruhi oleh beberapa faktor. Kompetensi pedagogik guru dibutuhkan untuk membangkitkan semangat siswa dalam belajar, guru harus mampu untuk mengajak siswa berpikir kritis dan aktif dalam proses pembelajaran.

\section{B. Bagi Orang Tua dan Keluarga Umumnya}

Orang tua sebaiknya memperhatikan anak-anak terutama dalam hal pembelajaran. Perhatian keluarga dengan cara meningkatkan kualitas mendidik anak, memperhatikan anak ketika belajar di rumah dan mengontrol pola tingkah laku anak. Membina relasi antar anggota keluarga dengan baik. Memberikan motivasi, dan menyediakan sarana dan fasilitas belajar yang memadai sehingga anak lebih bersemangat belajar dan mampu meningkatkan hasil belajarnya.

\section{Bagi Siswa}

Terkait pergaulan teman sebaya mayoritas berada pada kategori sedang, siswa sebaiknya meningkatkan kualitas pertemanan dengan cara pandai memilih teman bergaul, berhati-hati ketika akan bergabung pada suatu kelompok pertemanan dan harus meningkatkan kepedulian terhadap teman sebaya.

\section{Bagi Peneliti Selanjutnya}

Penelitian selanjutnya diharapkan dapat mengembangkan ini dengan meneliti lebih lanjut dengan memperdalam penelitian melalui waktu penelitian yang lebih berkualitas sehingga didapatkan hasil yang lebih baik lagi, juga untuk variabel hasil belajar sebaiknya dilakukan pengukuran pada kualitas soal ujian yang digunakan.

\section{DAFTAR RUJUKAN}


Ahmad, Mohd Sharani. (2004). Mengurus Kanak-Kanak Yang Susah Belajar. Pahang: PTS Publications \& Distributors Sdn Bhd.

Dalyono. 2001. Psikologi Pendidikan. Jakarta : Rineka Cipta

Denzin, Norman K. 2009. Handbook of Qualitative Research: Terj. Dariyatno dkk. Jogjakarta: Pustaka Pelajar.

Ely Rizky, 2017. "The Effect of Family and School Cultural Environment Trough Self Efficacy on Student Learning Result" jurnal internasional Vol 3 No 3 November 2017

Gerungan. 2000. Psikologi Sosial. Bandung: Refika Aditama

Hasbullah. 2011. Dasar-dasar Ilmu Pendidikan. Jakarta: Rajawali Pers

Hurlock, E.B. 1999. Psikologi Perkembangan: Suatu Pendekatan Sepanjang Rentang Kehidupan.

Imam Bukhori, 2017. "Effect of Learning Motivation, Family Factor, School Factor and Commuity Factor on Students Learning Outcomes on Productive Subjects". jurnal intenasional pendidikan bisnis dan manajemen Vol 3 No 3 November 2017

Santrock, John W.2009. Perkembangan Anak. Edisi 11. Jakarta. Erlangga

Slameto. 2010. Belajar dan Faktor yang mempengaruhinya. Jakarta: Rineka Cipta.

Sugihartono, dkk. 2007. Psikologi Pendidikan. Yogyakarta: UNY Press.

Sugiyono. 2017. Metode Penelitian Kuantitatif, Kualitatif, dan R\&D. Bandung : Alfabeta,CV

Suharsimi, Arikunto. 2013. Dasar-dasar Evaluasi Pendidikan (Edisi Revisi). Yogyakarta: Bumi Aksara.

Sulistiarti, 2017. "Pengaruh motivasi, tipe belajar, lingkungan keluarga dan lingkungan masyarakat terhadap hasil belajar siswa". jurnal pendidikan ekonomi, manajemen dan keuangan Vol 2 no 1 bulan mei 2018

Wahidmurni, dkk. 2010. Evaluasi Pembelajaran. Yogjakarta. Nuha Litera

Walgito, Bimo. 2010. Pengantar Psikologi Umum. Yogyakarta: C.V Andi. 